\title{
Early Changes in Thyroid-Stimulating Antibody Activity following Radioiodine Therapy
}

\author{
Akheel A. Syed ${ }^{a}$ Carol Evans $^{a} \quad$ Marian Ludgate ${ }^{b}$ John H. Lazarus ${ }^{b}$ \\ Departments of a Medical Biochemistry and ${ }^{b}$ Medicine, University Hospital of Wales and University of Wales \\ College of Medicine, Cardiff, UK
}

\section{Key Words}

Graves' disease $\cdot$ Hyperthyroidism $\cdot$ Thyroid autoimmunity - Thyroid-stimulating hormone receptor antibody stimulating activity $\cdot$ Thyroid-stimulating antibody $\cdot$ Radioiodine therapy
0.73 ) and after (1.00 Sl; $95 \% \mathrm{Cl}: 0.74-1.26)$ treatment either. Conclusions: Radioiodine therapy for GD or TMNG did not induce a significant change in TRAb-S activity at 3 months after treatment with ${ }^{131}$, probably due to effective antithyroid therapy or the timing of samples.

Copyright $\odot 2003$ S. Karger AG, Basel

\begin{abstract}
Objective: The aim of this study was to determine whether or not the titre of thyroid-stimulating hormone receptor antibody with stimulating (TRAb-S) activity changes in patients with Graves' disease (GD) or toxic multinodular goitres (TMNG) 3 months after treatment with sodium iodide (131I). Subjects and Methods: Serum specimens were obtained from 21 hyperthyroid patients ( 15 with GD and 6 with TMNG) at a median 0.5 months before and 3 months after ${ }^{131}$ | treatment using a standard ablative dose of $555 \mathrm{MBq}$. TRAb-S activity was measured in a sensitive and specific luminescent bioassay employing the lulu cell line and expressed as a stimulation index (Sl; normal s1.5). Results: The mean TRAb-S in the GD patients was $2.72 \mathrm{SI}(95 \% \mathrm{Cl}$ : 1.51-4.03) 0.5 months before administration of ${ }^{131}$ and $3.98 \mathrm{SI}(95 \% \mathrm{Cl}: 1.20$ 6.76) 3 months after administration of ${ }^{131}$. The difference was not statistically significant at $p<0.8$. It was not elevated in the TMNG patients before $(0.57 \mathrm{SI} ; 95 \% \mathrm{Cl}$ : $0.41-$
\end{abstract}

\section{KARGER}

Fax +41613061234

E-Mail karger@karger.ch

www. karger.com
(C) 2003 S. Karger AG, Basel

1011-7571/03/0124-0266\$19.50/0

Accessible online at:

www. karger.com/mpp

\section{Introduction}

Sodium iodide-131 ( $\left.{ }^{131} \mathrm{I}\right)$ is increasingly advocated as the definitive treatment of choice in patients with hyperthyroidism [1]. Changes that occur in thyroid autoimmunity after treatment of Graves' disease (GD) with ${ }^{131}$ I include a rise in thyroid-stimulating hormone receptor antibody with stimulating (TRAb-S) activity [2, 3]. Longterm changes in the titre of TRAb-S that may influence thyroid function have been noted years after ${ }^{131}$ I treatment [4]. Chiovato et al [5] observed a significant increase in TRAb-S 6 months after ${ }^{131}$ I treatment in patients who later developed hypothyroidism, and they postulated that the release of thyroid-stimulating hormone receptor (TSH-R) molecules from follicular cells as a consequence of radioiodine-induced thyroid cell damage may boost the immune response and result in the increased TRAb-S activity. Thus the TRAb-S status following ${ }^{131}$ I treatment 
may be predictive of the clinical outcome of thyroid function and could influence the further management of the patient.

The aim of this study was to determine whether or not the autoimmune changes in TRAb-S activity in serum of hyperthyroid patients treated with an ablative dose of ${ }^{131} \mathrm{I}$ appear earlier than previously reported by using a highly sensitive and specific human TSH-R bioassay.

\section{Subjects and Methods}

Twenty-one hyperthyroid subjects, 15 with GD and 6 with toxic multinodular goitres (TMNG), were included in the study. GD was diagnosed on clinical features plus the presence of elevated serum thyrotropin-binding-inhibiting immunoglobulin (TBII) titres $(>15 \%$ inhibition), and TMNG was also diagnosed on clinical features plus undetectable TBII titres. A ${ }^{131}$ I thyroid scan performed on the day of ablative treatment was used as additional evidence for diagnosis and to confirm a 4-hour uptake $>4 \%$ as indicative of satisfactory iodide trapping. Carbimazole was used as the antithyroid therapy of choice to render patients euthyroid, maintained up to 5 days prior to ${ }^{131} \mathrm{I}$ therapy, resumed $72 \mathrm{~h}$ after treatment and finally discontinued 6 weeks later. Each patient was given a standard ablative dose of $555 \mathrm{MBq}(15 \mathrm{mCi})$. Paired serum samples were obtained at a median 0.5 months before and 3.0 months after ${ }^{131}{ }^{1}$ treatment, and TRAb-S activity was measured in a luminescent bioassay using the lulu cell line (Chinese hamster ovary cells stably transfected with human TSH receptor and a cyclic-adenosine-monophosphate-dependent luciferase-responsive reporter) [6]. Lulu cells were seeded in 96-well plates, and serum was added at $10 \%$. Luciferase expression was quantified as emission of light in the presence of luciferin. Results were expressed as a stimulation index (SI) of light output from a subject's serum to light output from control serum. The 97.5 percentile of euthyroid serum (1.5 SI) was used as the cut-off. The Mann-Whitney $\mathrm{U}$ test was used to assess statistical significance.

\section{Results}

The mean TRAb-S activity in the patients with GD was $2.72(1.51-4.03)$ and $3.98(1.20-6.76)$ at 0.5 months before and 3 months after ${ }^{131}$ I therapy, respectively. The corresponding SI values for patients with TMNG were 0.57 (0.41-0.73) and 1.00 (0.74-1.26; fig. 1). The difference in titre before and after treatment was not statistically significantly different $(p<0.8)$. In the GD group, 8 of the 15 subjects had elevated TRAb-S activity before radioiodine treatment. Seven continued to have a raised activity at 3 months whilst 1 returned to normal. Two subjects with normal pretreatment TRAb-S developed increased activity after treatment. None of the 6 patients with TMNG had elevated TRAb-S activity either before or after treatment.

Changes in TRAb-S after ${ }^{131}$ I

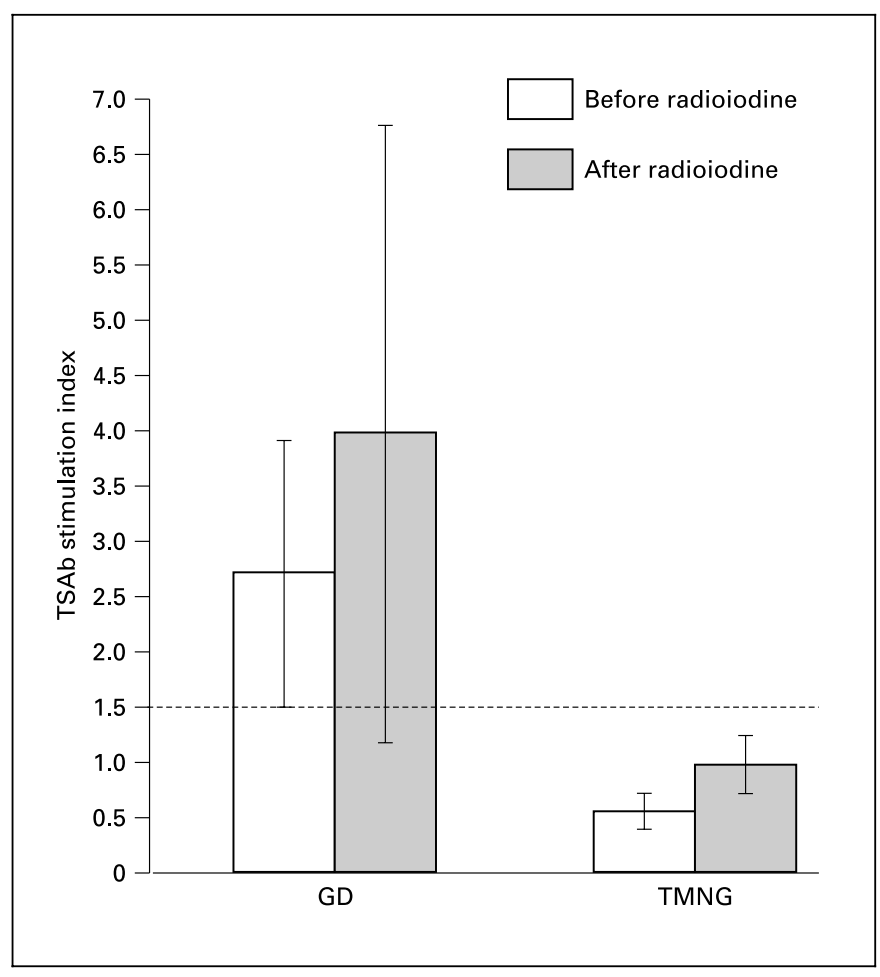

Fig. 1. Mean TRAb-S activity 0.5 months before and 3 months after ablative radioiodine therapy in hyperthyroid subjects with GD and TMNG. TRAb-S activity is expressed as an SI (normal $\leq 1.5$ ). Error bars represent $95 \%$ confidence intervals.

\section{Discussion}

Three months after a standard ablative dose of ${ }^{131} \mathrm{I}$ had been administered to patients with GD pretreated with carbimazole, TRAb-S activity as measured in a sensitive and specific human TSH-R bioassay showed no significant change probably due to effective antithyroid drug therapy and/or earlier sampling of serum than previously reported [5]. It seems that changes in the titre of TRAb-S do not occur 3 months after ablative treatment with ${ }^{131} \mathrm{I}$; however, further studies will be required to confirm this observation.

An increase in TRAb-S titres has been reported following ${ }^{131}$ I treatment in some patients with TMNG and variously interpreted as the induction of autoimmunity by ${ }^{131}$ I-induced thyroid cell damage, the unmasking of preexisting GD or a temporary side-effect without further clinical relevance [7, 8]. In this study, we did not observe a similar effect on TMNG patients as the serum sampling was done earlier than 6 months. It should also be noted that the sample size of this study was small. 


\section{Conclusion}

In this study on 21 hyperthyroid patients, a significant change in TRAb-S activity was not noticed 3 months after treatment with ${ }^{131} \mathrm{I}$, probably due to effective antithyroid therapy or the timing of samples.

\section{Acknowledgements}

We are grateful to Barry Nix, Department of Statistics, University of Wales College of Medicine, for advice on statistical methods.

\section{References}

1 Lazarus JH: Guidelines for the use of radioiodine in the management of hyperthyroidism: A summary. Prepared by the Radioiodine Audit Subcommittee of the Royal College of Physicians Committee on Diabetes and Endocrinology, and the Research Unit of the Royal College of Physicians. J R Coll Physicians Lond 1995;29:464-469.

2 Pinchera A, Liberti P, Martino E, Fenzi GF, Grasso L, Rovis L, Baschieri L, Doria G: Effects of antithyroid therapy on the long-acting thyroid stimulator and the antithyroglobulin antibodies. J Clin Endocrinol Metab 1969; 29:231-238.
3 Atkinson S, McGregor AM, Kendall-Taylor P, Peterson MM, Smith BR: Effect of radioiodine on stimulatory activity of Graves' immunoglobulins. Clin Endocrinol 1982;16:537-543.

4 Yoshida K, Aizawa Y, Kaise N, Fukazawa H, Kiso Y, Sayama N, Mori K, Hori H, Abe K: Relationship between thyroid-stimulating antibodies and thyrotropin-binding inhibitory immunoglobulins years after administration of radioiodine for Graves' disease: Retrospective clinical survey. J Endocrinol Invest 1996;19: 682-686.

5 Chiovato L, Fiore E, Vitti P, Rocchi R, Rago T, Dokic D, Latrofa F, Mammoli C, Lippi F, Ceccarelli C, Pinchera A: Outcome of thyroid function in Graves' patients treated with radioiodine: Role of thyroid-stimulating and thyrotropin-blocking antibodies and of radioiodineinduced thyroid damage. J Clin Endocrinol Metab 1998;83:40-46.
6 Evans C, Morgenthaler NG, Lee S, Llewellyn $\mathrm{DH}$, Clifton-Bligh R, John R, Lazarus JH, Chatterjee VK, Ludgate M: Development of a luminescent bioassay for thyroid stimulating antibodies. J Clin Endocrinol Metab 1999;84: 374-377.

7 Nygaard B, Faber J, Veje A, Hegedus L, Hansen JM: Transition of nodular toxic goiter to autoimmune hyperthyroidism triggered by ${ }^{131} \mathrm{I}$ therapy. Thyroid 1999;9:477-481.

8 Wallaschofski H, Muller D, Georgi P, Paschke $\mathrm{R}$ : Induction of TSH-receptor antibodies in patients with toxic multinodular goitre by radioiodine treatment. Horm Metab Res 2002; 34:36-39. 